\title{
The political context of reforms and the condition of the Polish school during the first term of rule of Law and Justice
}

\section{Polityczny kontekst reform i kondycja polskiej szkoły w trakcie pierwszej kadencji rządów Prawa i Sprawiedliwości}

\author{
Natalia Stępień-Lampa*
}

\begin{abstract}
The article characterizes the most important changes in the school system undertaken in 2015-2019 and the political context of these changes. The author analyzes the increase in compulsory education age and the assumptions of the education system reform as a result of which junior high schools were closed. The next part presents the public opinion about the Polish school and its implemented change. The final issue taken up in the study is the results of the PISA 2018.
\end{abstract}

Key words: the school system reform, the shutdown of the junior secondary schools, the political context of the educational changes, the social moods, PISA 2018

\begin{abstract}
Abstrakt
W artykule scharakteryzowano najważniejsze zmiany $\mathrm{w}$ ustroju szkolnym podjęte w latach 2015-2019 i polityczny kontekst tych zmian. Analizie poddano podwyższenie wieku obowiązkowej edukacji oraz założenia reformy systemu oświaty, w wyniku której m.in. zlikwidowano szkoły gimnazjalne. W dalszej części przedstawiono zdanie opinii publicznej na temat polskiej szkoły oraz wprowadzanej w niej zmiany. Ostatnią kwestią podjętą w opracowaniu są wyniki badania PISA 2018.
\end{abstract}

Słowa kluczowe: reforma systemu oświaty, likwidacja gimnazjów, podwyższenie wieku obowiązkowej edukacji, nastroje społeczne, PISA 2018

* Institute of Political Science, University of Silesia in Katowice (natalia.stepien@ us.edu.pl); iD https://orcid.org/0000-0001-6282-5655. 
Elections to the Sejm and Senate of the Republic of Poland were held on October 13, 2019. As a result, Law and Justice (PiS), ruling over the previous four years, polled $43.59 \%$ of votes, which translated into 235 seats in the Sejm. The second political power of the lower house was Civic Coalition (KO) (27.40\% support and 134 seats), the Democratic Left Alliance (SLD) came in third (12.56\% votes and 49 seats), and the fourth was the Polish People's Party (PSL) $(8.55 \%$ and 30 seats) ${ }^{1}$. Confederation Liberty and Independence (KWiN) also entered to the newly elected Sejm with a result of $6.81 \%$, which gave the party 11 seats. On the other hand, PiS received 48 seats, KO 43, PSL 3, SLD 2, and 3 seats were won by independent senators in the Senate.

The voter turnout in the elections to the Sejm peaked at $61.74 \%$, which was the highest result in the history of Polish elections after 1989 (Państwowa Komisja Wyborcza, 2019a). Jarosław Kaczyński’s political group polled exactly the same number of seats in the Sejm as in 2015 despite the fact that $37.58 \%$ of the voters supported the party at the turnout of $50.92 \%$ at the time. The same number of deputies entering to the Sejm in 2015 and 2019 resulted from the fact that in the previous elections only four committees crossed the electoral threshold. In turn, PiS achieved a much better result in 2015 in the Senate elections (in which votes are cast in single-mandate constituencies), gaining 61 seats (Państwowa Komisja Wyborcza, 2019b).

The difference in the share of votes of PiS voters in elections to the Sejm in 2015 and 2019 amounted to six percentage points in favor of this party with a turnout higher of more than ten percentage points. This enables drawing the conclusion that voters expressed their approval of the political program of Law and Justice implemented in the 2015-2019 term and supported the changes declared by this party in the election program. This observation also applies to transformations in the education system which were initiated by PiS on December 29, 2015 (Act, 2015). The age of compulsory school education was increased to seven years at the time. However, the most profound change was the reform of the school system, symbolized by phasing out of junior high schools completed on August 31, 2019 (Act 2016a, Act 2016b).

This study analyzes the assumptions of major changes in the education system that have been implemented by Law and Justice and the opinions of Polish people on this topic. This examination allowed drawing conclusions and outlining public sentiments towards school institutions in Poland. The article also contains an analysis of the results of the PISA 2018 study and the conclusions that can be drawn from it.

The first change in the education undertaken by the Law and Justice government was to increase the starting age of school education. This problem was

${ }^{1}$ Apart from SLD, the electoral committee of the Democratic Left Alliance also included Wiosna and Lewica Razem parties. In turn, the electoral committee of PSL gathered people associated with Paweł Kukiz outside of the People's party. 
one of the key topics of the election campaign (presidential and parliamentary) in 2015, which resulted from the lack of public support for the reform reducing the age of school initiation. During the 2011-2015 term of government, under the Act amending the Education System Act (so-called "Act on six-year-olds"), it was decided that in the 2014/2015 school year all children born in the first half of 2008 would be subject to compulsory education, while parents of children from the second half of that year were given the right to choose - they could send children to school or continue their pre-school education. Whereas in the 2015/2016 school year, first-year education was received by six-year-old children (born in 2009) and seven-year-olds from the second half of 2008 who previously attended the so-called zero grade (Act, 2013). After taking over power in 2015, PiS submitted to the Sejm a bill amending this state of affairs, i.e., an act that restored compulsory schooling for seven-year-old children and compulsory pre-school education for six-year-olds. The relevant legal act was passed on December 29, 2015 and entered into force on January 23, 2016. Therefore, this change was undertaken in less than one and a half months of the beginning of the eighth term of the Sejm and the ninth term of the Senate. As a result, starting from the 2016/2017 school year, seven-year-olds were obliged to attend school. The Act also imposed the obligation on six-year-old children to undergo a preschool preparation program in kindergarten or other pre-primary education. In addition, the Act confirmed the right of three-five-year-old children to benefit from pre-primary education (Act, 2015).

On September 1, 2019, as a result of the reform initiated by the legislation of December 14, 2016, junior high schools ceased to operate. It seems significant that the closure took place exactly 20 years after their creation. In addition to the liquidation, and in principle, according to the term used by the creators of the reform, the phasing-out of junior high schools, there were several other changes in the school system. After the reform process, the structure of the education system will be designated by: eight-year primary schools, four-year general high schools, five-year technical schools, three-year first-degree trade schools, twoyear second-degree trade schools, post-secondary schools (Ministry of National Education, 2016a). The assumptions of the change are implemented gradually on September 1, 2017, pupils of the sixth-year primary school became pupils of the eight-year school, and graduates of sixth grade started education in seventh grade. At the same time, it was then that the phasing-out of junior high schools began, and basic vocational schools evolved into three-year first-degree trade schools (two-year second-degree trade schools will be launched on September 1 2020). The reform will end in 2023, because it is then that the last year of junior high school graduates will complete a four-year technical school (Ministry of National Education, 2016a).

The reform of the education system aroused much controversy and focused public attention from the very beginning. In January 2017, the Public Opinion 
Research Center asked Poles for an opinion on the Polish school and the planned change. Public primary schools received the most positive reviews $(66 \%$ of respondents indicated that the level of education in these schools is very good or good). The least positive opinion was expressed on basic public vocational schools ( $47 \%$ of those participating in the survey described the level of education in those schools as very good or good). ${ }^{2}$ However, a significant proportion of respondents did not have an opinion on this topic. After considering the opinions of only those respondents who rated individual types of schools, it turned out that the respondents expressed the best opinions toward high schools (85$86 \%$ of positive opinions). In contrast, junior high schools were relatively the worst $-71 \%$ of people rated them well and $29 \%$ rated them badly. ${ }^{3}$ On the other hand, the analysis of the responses of individual groups of respondents leads to the conclusion that parents of school-age children rated the school system and individual types of schools better than respondents in general. $75 \%$ of parents expressed a good opinion on primary schools, $60 \%$ on junior high schools, $64 \%$ on high schools, $59 \%$ on technical schools, and $51 \%$ on basic vocational schools.

There is also a visible diversity of respondents' opinions declaring different political views. Teaching in public primary schools was well rated by $55 \%$ of supporters of Law and Justice, while public junior high schools were approved by $38 \%$ of supporters of this party. Bad opinions on these types of schools were declared by $29 \%$ and $39 \%$ of PiS supporters, respectively. Among the supporters of the then largest opposition party, Civic Platform (PO), the distribution of votes was different. The level of education in public primary schools was positively assessed by $75 \%$ of them, while in public junior high school by $64 \%$. In turn, $9 \%$ and $8 \%$ of PO supporters assessed them negatively. Interestingly, there is no diversity of opinion in the assessment of the level of high schools.

The survey also provided information on the age preferred by Poles to start school education. $58 \%$ of respondents were in favor of compulsory schooling for

2 The distribution of individual answers to the question about the level of education in Poland was as follows: public primary schools — very good $9 \%$, good $57 \%$, rather bad $14 \%$, very bad $3 \%$, hard to say $17 \%$; public junior high schools - very good $6 \%$, good $47 \%$, rather bad $16 \%$, very bad $5 \%$, hard to say $26 \%$; public general secondary schools - very good $8 \%$, good $51 \%$, rather bad $9 \%$, very bad $2 \%$, difficult to say $30 \%$; public technical schools - very good $8 \%$, good $49 \%$, rather bad $8 \%$, very bad $1 \%$, hard to say $35 \%$; public basic vocational schools - very good $5 \%$, good $42 \%$, rather bad $10 \%$, very bad $2 \%$, difficult to say $42 \%$ (Centrum Badania Opinii Społecznej, 2017, p. 1).

3 The distribution of individual answers, excluding the "hard to say" option, was as follows: public primary schools — very good $11 \%$, good $69 \%$, rather bad $17 \%$, very bad $3 \%$; public lower secondary schools — very good $8 \%$, good $63 \%$, rather bad $22 \%$, very bad $7 \%$; public general secondary schools - very good $12 \%$, good $73 \%$, rather bad $13 \%$, very bad $2 \%$; public technical schools — very good $12 \%$, good $74 \%$, rather bad $12 \%$, very bad $2 \%$; basic public vocational schools — very good $8 \%$, good $72 \%$, rather bad $17 \%$, very bad $3 \%$ (Centrum Badania Opinii Społecznej, 2017, p. 2). 
seven-year-old school children, 35\% supported sending six-year-olds to schools (Centrum Badania Opinii Społecznej, 2017, pp. 3-6).

The results of the survey conducted by CBOS in January 2017 allow the conclusion that Polish society assessed the level of education in individual types of schools relatively well. Basic vocational schools enjoyed relatively bad opinions. This fact was not surprising, since these schools had been chosen by a small group of the weakest students of each grade for many years. Subsequent education ministries presented their ideas for rectifying vocational education in Poland, but unfortunately they proved to be ineffective. ${ }^{4}$ Junior high schools also received unfavorable ratings of respondents. This effect was strengthened when the opinion of PiS supporters was taken into account, which in turn could also indicate the support of this party voters for political changes in the education system. Furthermore, the majority of people who took part in the survey turned out to be supporters of the starting age of school education up to seven years. This means that the ruling party enjoyed social legitimacy in this respect, particularly strongly expressed by PiS voters at the time of implementing thorough changes in the education system.

CBOS also asked respondents about their opinions on the reform of the education system adopted by parliament a month earlier. As the results of the study show, Polish society was divided on this issue. $34 \%$ of respondents build up more hopes than fears on the reform, 31\% had mixed feelings, and $27 \%$ more often expressed fears than they believed in the success of this undertaking. At the same time, $94 \%$ of those who took part in the survey declared that they had heard about the reform, but only $49 \%$ indicated that they knew what it would be about. In addition, $51 \%$ of respondents said that this change was going in the right direction, $33 \%$ said it was in the wrong direction. However, only $28 \%$ said that it was well prepared, while $44 \%$ rated its preparation as bad. Interestingly, the higher the level of education was, the higher earnings per capita, the larger the place of residence, as well as the less frequent participation in religious practices, the fears and beliefs that the reform was poorly prepared were greater.

Similar to the assessment of pre-reform school teaching, respondents with differing political preferences also differed in their attitude to education reform. $85 \%$ of PiS supporters said the change was heading in the right direction, and $55 \%$ said it was well prepared. On the other hand, $21 \%$ and $9 \%$ of PO supporters gave positive answers to these questions respectively.

On the other hand, the majority of respondents (57\%) accepted the closure of junior high schools and a return to eight-year primary school, four-year high school and five-year technical school. $24 \%$ of respondents opposed changes in

${ }^{4}$ For example, the Ministry of National Education, headed by Joanna Kluzik-Rostkowska, carried out a campaign promoting education in vocational schools and declared 2014 "The Year of the Professionals' School” (Kancelaria Prezesa Rady Ministrów, 2014). 
the school system, while $19 \%$ did not have an opinion on this topic. Almost half of the people (44\%) who took part in the survey thought that the reform would be a great financial burden for local governments (Centrum Badania Opinii Społecznej, 2017, pp. 7-12). The results of the survey conducted by CBOS were largely in line with the moods that prevailed in the media around the change in the education system at the turn of 2016 and 2017. The issues raised in the survey were often addressed by experts, and were also extensively commented on by politicians.

The reform of the education system designed by Law and Justice began on September 1, 2017. A year later, CBOS again asked Poles about their opinions on the functioning of the school system. The respondents again expressed their good opinion about the level of education in Polish schools. Nevertheless, the share of positive reviews decreased compared to the 2017 survey. In August 2018 , public primary school was rated very well and rather well by $56 \%$ of respondents, bad and rather bad - 22\%, public junior high schools $41 \%$ and $27 \%$ respectively, public general high schools $52 \%$ and $11 \%$, public technical schools $51 \%$ and $8 \%$, public vocational schools $41 \%$ and $12 \%$, public trade schools (i.e., entities that replaced vocational schools) $33 \%$ and $8 \%$, with as much as $59 \%$ of respondents having no specific opinion in this regard. ${ }^{5}$

Interestingly, despite the worse assessment of the Polish school, the respondents expressed a favorable opinion on the school system introduced under the December 2016 reform. 67\% thought it was better than the previous one, including $37 \%$ who considered it as definitely better. The opposite view was expressed by $21 \%$ of respondents, including $8 \%$ being extremely critical of the education system without junior high schools. The structural change was approved mainly by those respondents who themselves attended an eight-year primary school (72\%). The analysis of the respondents' political preferences and their opinions on the reform leads to the conclusion that among the electorate of all political parties represented in the Sejm, except for Nowoczesna, the supporters of the new school system prevailed. However, the biggest endorsement of the change was expressed by PiS supporters (87\% accepted the reform) and Kukiz'15 $(84 \%)$. Among the PO voters, $51 \%$ of the respondents approved the new school structure. In the case of Nowoczesna - 36\% of its supporters supported the change.

5 After excluding the "hard to say" response, the distribution was as follows: public primary schools - very good $11 \%$, good $61 \%$, rather bad $22 \%$, very bad $6 \%$; public junior high schools - very good $6 \%$, good $55 \%$, rather bad $30 \%$, very bad $9 \%$; public general high schools - very good $12 \%$, good $70 \%$, rather bad $16 \%$, very bad $2 \%$; public technical schools - very good $12 \%$, good $75 \%$, rather bad $12 \%$, very bad $1 \%$; public vocational schools - very good $9 \%$, good $68 \%$, rather bad $18 \%$, very bad $5 \%$; public trade schools very good $8 \%$, good $74 \%$, rather bad $14 \%$, very bad $4 \%$ (Centrum Badania Opinii Społecznej, 2018, pp. 1-4). 
According to CBOS, the majority of Poles thought that a reform of the education system was needed (52\% of respondents against $37 \%$ expressing a contrary opinion), nevertheless the respondents had major concerns regarding its preparation. $40 \%$ expressed negative opinions in this matter, whereas only $29 \%$ positive. Furthermore, the manner in which the educational change was implemented raised some doubts. $36 \%$ of respondents positively assessed the method of its implementation, and $31 \%$ had a contrary opinion. In addition, political views again determined the answers given by the respondents. Mainly people with right-wing views, including supporters of Law and Justice, underpinned the legitimacy of the reform, the way it was prepared and implemented. The need for reform was also recognized by supporters of the Polish People's Party and the Kukiz'15 movement. Other voters rather expressed the belief that there was no need for change and in particular, that the reform was badly prepared and not properly implemented (Centrum Badania Opinii Społecznej, 2018, pp. 6-10).

The results of the CBOS survey conducted in August 2018 show public support for structural reform in the education system. Nevertheless, the respondents had some objections to it. They were mainly related to the method of preparation and implementation of the change. The excessive haste of the reformers was a source of many small failures, which was particularly evident when creating new core curricula.

Despite the generally unfavorable opinion of Poles about junior high schools - both before undertaking the reform of the education system and a year after the start of its implementation - a preliminary analysis of the results of the latest PISA survey shows a relatively good level of teaching in these schools. The PISA study, or Program for International Student Assessment, has been organized by the OECD (Organization for Economic Co-operation and Development) since 2000. The last round of the survey took place in 2018 and 79 countries and regions took part in it. PISA tests mathematical skills, reasoning in natural sciences, and reading and interpretation of 15-year-old students (exactly those who turned 15 in the year preceding the study).

The last round of the PISA survey took place during the implementation of the school reform in Poland. The vast majority of respondents was the penultimate year of junior high school students (97.5\%), only a few were students of primary or high schools. The 2018 round was attended by students born in 2002 . 5653 people participated in the survey (which constituted $85 \%$ of the sample), and it was carried out between March 1 and April 13 (Instytut Badań Edukacyjnych, 2019, pp. 4-7).

The results achieved by Polish students in PISA 2018 were one of the best in the history of the study. In terms of reading comprehension, they took 10th place in the world and 4th in Europe. At the same time, the result achieved in 2018 (512 points) was significantly higher than in the previous round (506) 
and lower than in 2012 (518). However, compared to the first survey in 2000, we can observe an upward trend - initially the results of 15-year-olds from Poland were lower than the OECD average, while in recent rounds they were at the forefront. In 2018, the average result for OECD countries in the case of understanding the written text was 489 points. Also, the mathematical skills of Polish students compared to other countries have allowed them to rank 10 in the world. In Europe, in turn, Poland took 3rd place. ${ }^{6}$ The average result of Polish students in 2018 (516 points) did not differ statistically from the result from 2012 (518 points), which was the highest in history. In the case of mathematics, an upward trend can also be observed. The difference between the first - in which comparisons are possible (2003) - and the last round of the study was as many as 26 points. The result achieved in 2018 by 15 -year-olds from Poland was much higher than the average for OECD countries (again 489 points). However, in the case of reasoning in the natural sciences, Polish students managed to take 11th place in the world and 3rd in Europe. ${ }^{7}$ The average result of Polish students in 2018 (516 points) did not differ statistically from the result from 2012 (518 points), which was the highest in history. In the case of mathematics, an upward trend can also be observed. The difference between the first - in which comparisons are possible (2003) - and the last round of the study was as many as 26 points. The result achieved in 2018 by 15 -year-olds from Poland was much higher than the average for OECD countries (again 489 points). However, in the case of reasoning in the natural sciences, Polish students managed to take 11th place in the world and 3rd in Europe. ${ }^{8}$ Comprehensive science competences in the PISA study were first tested in 2006. Since then, the results of Polish students have been marked by an upward trend, and the difference between the first (2006) and the last round of the study is 13 points. The 2018 result (511 points) in the field of life sciences was again higher than the OECD average (in this case it was also 489 points).

Very good results of the PISA survey provided arguments to junior high school students to criticize the reform and the resulting closure of junior high schools. Perhaps, however, they are the result of an improvement in the condition of the Polish school or the way of teaching, and they were slightly affected by the school structure? Maybe students in Poland just learned to take tests very

${ }^{6}$ The top ten were as follows: 1. China (excluding selected regions), 2. Singapore, 3. Macau (China), 4. Hong Kong (China), 5. Taiwan, 6. Japan, 7. South Korea, 8. Estonia, 9. The Netherlands, 10. Poland (Instytut Badań Edukacyjnych, 2019, pp. 12-15).

7 The top ten were as follows: 1. China (excluding selected regions), 2. Singapore, 3. Macau (China), 4. Estonia, 5. Japan, 6. Finland, 7. South Korea, 8. Canada, 9. Hong Kong (China), 10. Taiwan (Instytut Badań Edukacyjnych, 2019, pp. 16-19).

${ }^{8}$ The top ten were as follows: 1. China (excluding selected regions), 2. Singapore, 3. Macau (China), 4. Estonia, 5. Japan, 6. Finland, 7. South Korea, 8. Canada, 9. Hong Kong (China), 10. Taiwan (Instytut Badań Edukacyjnych, 2019, pp. 16-19). 
well? The PISA 2018 results also contained some disturbing data on the condition of the Polish school. In addition to checking the skills and competences in the study, some questions are also asked related to the subjects of teaching and regarding the student's functioning at school. These questionnaires focus on the mental and emotional health of the student, the role of the teacher and the parent, or the school's social life. The answers given by Polish 15-year-olds within this group of questions are generally not optimistic. For example, only $62 \%$ of them felt life satisfaction, while the OECD average was $67 \%$. The only European country that was in the top ten in all three areas of the study (reading, mathematics, science) - Estonia - had students' life satisfaction at 70\%. Furthermore, $87 \%$ of Polish students have sometimes or always felt happy, while the OECD result is $91 \%$ and Estonia's $89 \%$. In turn, $8 \%$ of young Poles have always felt sad, the OECD average was 6\%. For this answer, Estonia recorded a result of $9 \%$. An important problem in the Polish school, which PISA confirmed, is bullying. $26 \%$ of those surveyed said they had experienced at least one form of bullying at least five times a month. The results for OECD and Estonia were $23 \%$ and $25 \%$ respectively. In turn, $80 \%$ of students said joining in bullying was something wrong, $88 \%$ in OECD and $89 \%$ in Estonia. The time devoted to learning by Polish teenagers is also disturbing. It amounted to 47 hours, while the OECD average is 44 hours and for Estonia 42. This may mean that the educational success of young Poles in the study was at a very high cost. When we consider the answers to questions about support that teachers give to students in the learning process, the condition of the Polish school is not good again. In this group of questions, Poland came 5th from the end - $62 \%$ of students thought that teachers showed interest in the student and how they were learning; $68 \%$ said teachers gave them extra help when needed; $65 \%$ declared that teachers help students learn and $61 \%$ said that teachers continue teaching until all students understand the issues explained (OECD, 2019).

The results of the international survey among 15-year-olds, which is PISA, are favorable for the education system in Poland. Polish students were at the forefront of students from the OECD countries or regions. Supporters of junior high schools and standardized tests as a measure of student achievement have certainly felt great satisfaction thanks to them. However, the data illustrating the mental condition of young people in Poland are worrying. What is worse, the reform of the education system undertaken by PiS, focusing on the closure of junior high schools, will not solve it in any way, because it does not concern this problem. PISA 2021 will definitely provide us with information about the level of knowledge and skills of test solving that students in eight-year primary schools will have. It will provide supporters or opponents of the reform with a strong argument for or against the educational change that is being implemented. At the same time, despite the fact that many teachers, students and their parents face numerous problems in connection with school reality, political 
decision-makers are still arguing about the shape of the school system or about the legitimacy of functioning of junior high schools. Possible further education reforms will only deepen the chaos that prevails in the system. There is an atmosphere of permanent change at school. The change is a permanent feature of Polish education.

The most negative statement from the analysis of the functioning of the school in Poland is that it has become an arena of political play. Politicians taking up subjects related to education very often count on securing the votes. For example, already in the election campaign, PiS announced an increase in the age of compulsory education from six to seven years and plans to close down junior high schools, which was done in order to win supporters. At the same time, these announcements were against the changes and plans that PO had implemented or intended to implement in the school system. In this political dispute around the school, aimed at courting popular opinion, the losers are not politicians. They are students, their parents and also education workers. In the current sociopolitical reality, it seems impossible to reach agreement across divisions and to reform education over political divisions. However, it is likely that each subsequent ruling team will make changes in education, which will largely be aimed at attracting supporters.

\section{References}

Centrum Badania Opinii Społecznej (2017). Komunikat z Badań Nr 16/2017. Polacy o reformie edukacji. Warszawa.

Centrum Badania Opinii Społecznej (2018). Komunikat z Badań Nr 122/2018. Ocena systemu edukacji po roku od wprowadzenia reformy. Warszawa.

Instytut Badań Edukacyjnych (2019). PISA. Wyniki badania 2018 w Polsce. Warszawa.

Kancelaria Prezesa Rady Ministrów (2014). https://www.premier.gov.pl/wydarze nia/aktualnosci/rusza-rok-szkoly-zawodowcow-cel-odbudowa-szkolnictwa-zawo dowego.html/ (dostęp: 18.10.2019).

Ministerstwo Edukacji Narodowej (2016a). http://reformaedukacji.men.gov.pl/o -reformie/uczen-i-rodzic/struktura-szkol-po-zmianach.html/ (dostęp: 18.10.2019).

Ministerstwo Edukacji Narodowej (2016b). http://reformaedukacji.men.gov.pl/o -reformie/uczen-i-rodzic/jak-beda-przebiegaly-zmiany-w-kolejnych-latach.html/ (dostęp: 18.10.2019).

OECD (2019). PISA 2018 Results. What school life means for student's lives. Vol. III. https://www.oecd.org/publications/pisa-2018-results-volume-iii-acd78851-en .htm/ (dostęp: 7.01.2020).

Państwowa Komisja Wyborcza (2019b). https://parlament2015.pkw.gov.pl/349 Wyniki_Sejm.html/ (dostęp: 17.10.2019). 
Państwowa Komisja Wyborcza (2019a). https://wybory.gov.pl/sejmsenat2019/ (dostęp: 17.10.2019).

Ustawa z dnia 30 sierpnia 2013 roku o zmianie ustawy o systemie oświaty oraz ustawy o zmianie ustawy o systemie oświaty oraz o zmianie niektórych innych ustaw (t.j. Dz.U. z 2013 r. poz. 1265 z późn. zm.).

Ustawa z 29 grudnia 2015 roku o zmianie ustawy o systemie oświaty oraz niektórych innych ustaw (t.j. Dz.U z 2016 r. poz. 35 z późn. zm.).

Ustawa z dnia 14 grudnia 2016 roku Prawo oświatowe (t.j. Dz.U. z 2019 r. poz. 1148 z późn. zm.).

Ustawa z dnia 14 grudnia 2016 roku Przepisy wprowadzające ustawę — Prawo oświatowe (Dz.U. z 2017 r. poz. 60 z późn. zm.).

Natalia Stępień-Lampa, PhD, assistant professor at the Institute of Political Sciences of the University of Silesia in Katowice. In her scientific work, she deals with issues related to the qeestion of equalizing educational opportunities, educational policy, the phenomenon of poverty, including its spatial concentration. She is a member of the Polish Society for Social Policy and the Polish Society of Political Sciences. She is a treasurer in the Association of Scientific Initiatives. In 2010 she graduated from the School of Business Trainers and in 2018 from the School of Academic Tutors. She is the coordinator of the University of Silesia in Youth and the University of the Best - an educational initiative of the University of Silesia directed at gifted students. She cooperates with the University of Silesian High School graduates and the University of Silesia for Teachers. 